\title{
STUDI DESKRIPTIF PERSIAPAN DOKUMEN AKREDITASI PUSKESMAS 2015 TENTANG PEMBAKUAN KODE DI PUSKESMAS NANGGULAN KULON PROGO
}

Ida Ayu Nur Faiza' ${ }^{1}$ Rawi Miharti ${ }^{1}$

'Program Studi Diploma III Rekam Medis Sekolah Vokasi Universitas Gadjah Mada, Email: idayunurfaiza@gmail.com

\begin{abstract}
Background: In the era of the ASEAN Free Trade Area (AFTA), the quality of health services is required to compete internationally. The data of diagnostic and procedure is one of the determinants of service quality. One of the ways to improve the quality of health services is to carry out accreditation. Puskesmas Nanggulan Kulon Progo prepared the documents about standardisation of code for Puskesmas Accreditation 2015. Furthermore, in National Health Insurance program (Jaminan Kesehatan Nasionalprogram) diagnostic and procedure codes are used as the terms to claim to Badan Penyelenggara Jaminan Sosial (BPJS).

Objective: This research aimed to explore the documents preparation of Puskesmas Accreditation 2015 regarding code standardisation at Puskesmas Nanggulan Kulon Progo.

Method: This research was a descriptive research with a qualitative approach. The design of the research used in this study was phenomenology. Data collection technique in this study was observation towards the documents of accreditation related to codestandardisation and interview withfive respondents who involvedin the accreditation team.

Results: The documents preparation forPuskesmas Accreditation 2015 regardingcodestandardisation was successfully completed. The preparation for accreditation related to code standardisation were as follow:

1. Man: planing the finance scheme,prepare documents related to accreditation, form a team of accreditation documents arrangement

2. Method: process of forming a team that will arrange the documents and the process of preparing the documents

3. Materials: preparing stationery for office use

4. Machines: preparing laptop (or computers) and printer

5. Money : meeting all the financial needs.

Conclusion:Documents preparation towards Puskesmas accreditation require human resource, methods, materials, machines, and fund.
\end{abstract}

Keywords: Accreditation, accreditation preparation, puskesmas accreditation, 5M, standardisation of the code.

\section{PENDAHULUAN}

Berdasarkan Permenkes RI Nomor 75 Tahun 2014, akreditasi puskesmas adalah pengakuan terhadap puskesmas yang diberikan oleh lembaga independen penyelenggara akreditasi yang ditetapkan oleh Menteri setelah dinilai bahwa puskesmas telah memenuhi standar pelayanan puskesmas yang telah ditetapkan oleh Menteri, untuk meningkatkan mutu pelayanan puskesmas secara berkesinambungan. ${ }^{(1)}$

Data penyakit dan tindakan termasuk dalam salah satu faktor penentu mutu pelayanan. Seperti yang dijelaskan dalam $\mathrm{Hatta}^{(2)}$ bahwa membandingkan data diagnosis untuk mengukur kepastian kualitas, pengunaan sumber daya, praktek yang prima, dan riset medis adalah sangat penting. Upaya ini bisa berhasil tercapai hanya apabila asuhan kesehatan memiliki terminologi medis penyakit dan kesehatan yang seragam dibidang prosedur diagnostik, terapi medis bedah atau pun obat, yang dimengerti, dan digunakan bersama yang akhirnya dapat dengan mudah diintegasikan ke rekam medis 
manual atau pun berbasis komputer, untuk memenuhi tren perkembangan zaman.

Salah satu persiapan akreditasi puskesmas 2015 yang dilakukan oleh puskesmas adalah penyiapan dokumen akreditasi. Berdasarkan standar akreditasi puskesmas yang terlampir dalam Permenkes $^{(3)}$ Nomor 46 Tahun 2015 terdapat empat kriteria dalam standar manajemen informasi rekam medis yaitu Ada pembakuan kode klasifikasi diagnosis, kode prosedur, simbol, dan istilah yang dipakai. Petugas memiliki akses informasi sesuai dengan kebutuhan dan tanggung jawab pekerjaan. Adanya sistem yang memandu penyimpanan dan pemrosesan rekam medis. Rekam berisi informasi yang memadai dan dijaga kerahasiaannya tentang identifikasi pasien, dokumentasi prosedur kajian, masalah, kemajuan pasien dan hasil asuhan.

Masalah dalam penelitian ini adalah bagaimana persiapan dokumen tentang pembakuan kode di Puskesmas Nanggulan Kulon Progo. Tujuan penelitian ini yaitu untuk mengetahui persiapan dokumen terkait rekam medis sesuai elemen penilaian pada manajemen informasi rekam medis yang berfokus pada pembakuan kode klasifikasi diagnosis, kode prosedur, simbol dan istilah yang dipakai dalam standar akreditasi puskesmas tahun 2015 di Puskesmas Nanggulan Kulon Progo.

\section{BAHAN DAN CARA PENELITIAN}

Jenis penelitian yang digunakan dalam penelitian ini adalah penelitian deskriptif dengan pendekatan kualititatif. Rancangan penelitian yang digunakan dalam penelitian ini adalah fenomenologi. Objek pada penelitian ini adalah lima orang dari tim akreditasi yang mempersiapkan dokumen akreditasi terkait pembakuan kode di Puskesmas Nanggulan Kulon Progo. Objek pada penelitian ini yaitu dokumen akreditasi puskesmas 2015 terkait pembakuan kode yang dimiliki oleh Puskesmas Nanggulan Kulon Progo.

Teknik pengumpulan data yang digunakan dalam penelitian ini adalah observasi (pengamatan) dan wawancara. Teknik validitas data yang gunakan dalam penelitian ini yaitu triangulasi sumber.Teknik analisis data yang digunakan dalam penelitian ini adalah teknik analisis data kualitatif yang dilakukan secara induktif yaitu pengambilan kesimpulan umum berdasarkan data-data yang telah terkumpul.

\section{HASIL DAN PEMBAHASAN}

Persiapan Akreditasi Puskesmas 2015 tersebut terbagi ke dalam dua persiapan yaitu persiapan dokumen dan persiapan pelaksanaan kinerja yang sesuai dengan standar prosedur operasi atau sering kita dengar dengan istilah SPO. Sebelum bulan Januari 2015 Puskesmas Nanggulan Kulon Progo belum memiliki dokumen terkait pembakuan kode. Setelah bulan November 2015 dokumen tentang pembakuan kode 
memang sudah ada. Akan tetapi, berdasarkan hasil observasi, penulisan dokumen pembakuan kode tersebut menggunakan bahasa Indonesia untuk menulis diagnosis. Peneliti meneliti persiapan dokumen akreditasi tentang pembakuan kode ini dari segi tenaga, biaya, bahan, metode dan alat.

Berikut ini merupakan hasil pengamatan terhadap dokumen Akreditasi Puskesmas 2015 tentang pembakuan kode di Puskesmas Nanggulan Kulon Progo.

Tabel 1.Daftar Klasifikasi Responden

\begin{tabular}{|c|c|c|c|c|c|}
\hline \multirow{2}{*}{ No } & \multirow{2}{*}{ Kode } & \multicolumn{3}{|c|}{$\begin{array}{c}\text { Lama } \\
\text { Kerja(Tahun) }\end{array}$} & \multirow{2}{*}{$\begin{array}{c}\text { Jenis } \\
\text { Kelamin }\end{array}$} \\
\hline & & $<5$ & $\begin{array}{l}5- \\
10\end{array}$ & $>10$ & \\
\hline 1 & $A$ & $\mathrm{~V}$ & & & Laki-laki \\
\hline 2 & $B$ & $\mathrm{~V}$ & & & Perempuan \\
\hline 3 & $C$ & $\mathrm{~V}$ & & & Perempuan \\
\hline 4 & D & & & V & Laki-laki \\
\hline 5 & $E$ & $\mathrm{~V}$ & & & Perempuan \\
\hline
\end{tabular}

Berikut ini merupakan hasil wawancara persiapan dokumen Akreditasi Puskesmas 2015 tentang pembakuan kode tersebut dari segi tenaga, metode, bahan, alat, dan biaya.

Tabel 2. Hasil Observasi Dokumen Akreditasi Puskesmas 2015 tentang Pembakuan Kode di Puskesmas Nanggulan Kulon Progo

\begin{tabular}{|c|c|c|}
\hline No & $\begin{array}{c}\text { Judul Dokumen yang } \\
\text { Diamati }\end{array}$ & Ada Tidak \\
\hline 1. & $\begin{array}{l}\text { SK tentang standarisasi kode } \\
\text { klasifikasi diagnosis dan } \\
\text { terminologi yang digunakandi } \\
\text { Puskesmas Nanggulan 1Kulon } \\
\text { Progo }\end{array}$ & V \\
\hline 2. & $\begin{array}{l}\text { Standarisasi kode kl-asifikasi } \\
\text { diagnosis dan terminologi di } \\
\text { Puskesmas Nanggulan Kulon } \\
\text { Progo }\end{array}$ & $\mathrm{v}$ \\
\hline 3. & $\begin{array}{l}\text { Pembakuan singkatan yang } \\
\text { digunakan di Puskesmas } \\
\text { Nanggulan Kulon Progo }\end{array}$ & V \\
\hline
\end{tabular}

\section{Tenaga}

Berikut ini merupakan rincian dari tim yang dimaksud tersebut:

Tim Pembuat Surat Keputusan (SK). Berdasarkan hasil observasi, SK memiliki kepanjangan surat keputusan. SK adalah surat keputusan yang ditetapkan oleh kepala puskesmas. Dokumen pembakuan kode dengan judul "SK tentang standarisasi kode klasifikasi diagnosis dan terminologi yang digunakandi Puskesmas Nanggulan Kulon Progo" dan "Pembakuan singkatan yang digunakan di Puskesmas Nanggulan Kulon Progo" berbentuk SK. Dokumen pembakuan singkatan berupa surat keputusan yang berisi pembakuan singkatan yang digunakan oleh dokter dari sepuluh besar diagnosis di Puskesmas Nanggulan Kulon Progo.

Pada awal Januari 2015 tiga petugas rekam medis di Puskesmas Nanggulan Kulon Progo belum ada yang berlatar belakang pendidikan rekam medis. Tiga petugas rekam medis tersebut memiliki latar belakang pendidikan terakhir Sekolah Lanjut Tingkat Atas (SLTA). Sehingga pembetukan tim yang dilaksanakan pada bulan Februari 2015 dimulai dengan merekrut pegawai dengan latar belakang pendidikan rekam medis. Perekrutan satu petugas rekam medis dengan latar belakang pendidikan rekam medis tersebut sesuai dengan hasil evaluasi kebutuhan petugas di Puskesmas Nanggulan Kulon Progo bahwa minimal terdapat satu petugas rekam medis dengan latar belakang pendidikan rekam medis. 
Tim pembuat dokumen surat keputusan tentang pembakuan kode terdiri dari dua orang petugas rekam medis. Kepala puskesmas juga merupakan bagian dari tim pembuat dokumen surat keputusan tentang pembakuan kode.

Tim pembuat standarisasi diagnosis terdiri dari empat tenaga.Tim pembuat dokumen ini terdiri dari petugas rekam medis yang berkoordinasi dengan dokter dan koder.

Dokumen yang dibuat yaitu dokumen dengan judul "SK tentang standarisasi kode klasifikasi diagnosis dan terminologi yang digunakandi Puskesmas Nanggulan Kulon Progo", "Standarisasi kode klasifikasi diagnosis dan terminologi di Puskesmas Nanggulan Kulon Progo", dan "Pembakuan singkatan yang digunakan di Puskesmas Nanggulan Kulon Progo". Proses pembuatan dokumen Akreditasi Puskesmas 2015 tentang pembakuan kode dimulai lima bulan sebelum penilaian Akreditasi Puskesmas 2015, yaitu dimulai bulan Juni 2015. Proses pembuatan dokumen akreditasi puskesmas tentang pembakuan kode dilaksanakan oleh tim yang sudah terbentuk. Selama proses pembuatan dokumen akreditasi puskesmas tentang pembakuan kode tim akan menggunakan sumber daya berupa bahan dan alat yang tersedia di Puskesmas Nanggulan Kulon Progo. Bahan yang dimaksud akan diuraikan pada sub bab bahan. Alat yang dimaksud akan diuraikan pada sub bab alat.

\section{Metode}

Metode yang dimaksud dalam penelitian ini yaitu langkah-langkah yang berkaitan persiapan dokumen akreditasi yang dilakukan oleh tenaga. Langkah-langkah tersebut yaitu langkah pembentukan tim yang akan membuat dokumen, langkah pembuatan dokumen yang akan menjelaskan proses pembuatan dokumen dan hal-hal yang berkaitan dengan pembuatan dokumen.

Berikut ini merupakan langkah-langkah yang dilaksanakan oleh tenaga untuk membentuk tim yang akan membuat dokumen akreditasi :

Analisis kebutuhan yaitu menghitung kebutuhan tenaga yang harus ditambahkan. Setelah dilakukan analisis kebutuhan tenaga Puskesmas Nanggulan memerlukan tenaga rekam medis dengan latar belakang pendidikan rekam medis.

Perekrutan dilakukan oleh Dinas Kesehatan Kulon Progo. Tahapan perekrutan yang dilaksanakan oleh Dinas Kesehatan Kulon Progo sebagai berikut ini melakukan pendaftaran di Dinas Kesehatan Kulon Progo. Memilih satu bagian kerja yang ditawarkan. Seleksi administrasi. Apabila lulus seleksi adminintrasi maka selanjutnya mengikuti tes tertulis. Apabila tidak lulus seleksi administrasi maka sudah tidak bisa mengikuti tahapan perekrutan yang selanjutnya. Seleksi tertulis dengan materi campuran. Apabila lulus seleksi tertulis maka selanjutnya mengikuti seleksi wawancara. Apabila tidak lulus seleksi tertulis maka sudah tidak bisa mengikuti tahapan perekrutan yang selanjutnya. 
Wawancara dengan materi terkait bagian kerja

Kaji banding merupakan sebuah konsep belajar yang dilakukan di lokasi dan lingkungan berbeda yang merupakan kegiatan yang lazim dilakukan untuk maksud peningkatan mutu, perluasan usaha, perbaikan sistem, penentuan kebijakan baru, perbaikan peraturan perundangan, dan lainlan. Tujuan utama melakukan studi banding nantinya adalah menggali sebanyak mungkin informasi yang bisa didapat scara teknis real dan empiris. Untuk dijadikan barometer dan pembanding yang kemudian masuk untuk menemukan sebuah pembaharuan yang aplikatif, baik untuk plan ke depan dalam jangka pendek dan jangka panjang secara futuristik.

Puskesmas

Nanggulan melaksanakan tiga kali kaji banding.

Referensi merupakan rujukan dari suatu informasi. Referensi yang dimaksud yaitu referensi yang berkaitan format dokumen akreditasi dan referensi untuk isi dokumen tersebut.

Dalam mempersiapkan dokumen terdapat pedoman penyusunan dokumen akreditasi yang diberikan oleh Komisi Akreditasi Puskesmas dalam bentuk soft file. Referensi ini memuat berbagai jenis dokumen dan formatnya.

Referensi ini berguna untuk membantu penyusunan isi dokumen. Dasar hukum ini diperoleh melalui pencarian di internet mau pun buku-buku terkait rekam medis.

\section{Bahan}

Dalam rangka mempersiapkan dokumen Akreditasi Puskesmas 2015, Puskesmas Nanggulan Kulon Progo melakukan penambahan terhadap bahan yang berkaitan dengan pembuatan dokumen. Bahan yang ditambah jumlahnya berupa Alat Tulis Kantor (ATK).

\section{Alat}

Dalam rangka mempersiapkan dokumen akreditasi, Puskesmas Nanggulan Kulon Progo menambah peralatan. Peralatan tersebut berupa mesin kantor yaitu dekstop sejumlah 1 buah, printer sejumlah 2 buah, dan laptop sejumlah 3 buah.

\section{Biaya}

Puskesmas Nanggulan Kulon Progo memiliki dana untuk kegiatan persiapan Akreditasi Puskesmas 2015. Dana ini tidak secara khusus dipisahkan dalam item persiapan Akreditasi Puskesmas 2015. Akan tetapi diwujudkan dalam penambahan biaya untuk alat, bahan, metode dan tenaga selama persiapan Akreditasi Puskesmas 2015.

Permenkes $^{(3)}$ Nomor 46 Tahun 2015 menyebutkan bahwa Puskesmas, Klinik Pratama, tempat praktik mandiri dokter, dan tempat praktik mandiridokter gigi wajib terakreditasi. Hasil penilaian akreditasi yang diperoleh oleh Puskesmas Nanggulan Kulon Progo yaitu terakreditasi dasar. Puskesmas Nanggulan Kulon Progo telah berhasil membuat dokumen tentang pembakuan kode untuk Akreditasi Puskesmas 2015. Kode diagnosis yang tercantum pada dokumen 
tersebut berdasarkan ICD-10. Akan tetapi penulisan diagnosis pada dokumen tersebut sebagian besar menggunakan Bahasa Indonesia dan pada pelaksanaannya masih ada tenaga medis yang menulis diagnosis menggunakan Bahasa Indonesia. Permenkes $^{(4)}$ RI Nomor 27 tahun 2014 menyebutkan bahwa penulisan diagnosis harus lengkap dan spesifik (menunjukkan letak, topografi, dan etiologinya). Diagnosis harus mempunyai nilai informatif sesuai dengan kategori ICD yang spesifik.

Harapannya penulisan diagnosis di berkas rekam medis mau pun dokumen pembakuan kode di Puskesmas Nanggulan Kulon Progo sesuai dengan penulisan diagnosis pada ICD. Rahasti ${ }^{(5)}$ menyebutkan bahwa ada keterkaitan antara penulisan diagnosis dengan ketepatan kode klasifikasi diagnosis. Artinya apabila penulisannya sesuai dengan yang sudah dicantumkan dalam dokumen kemudian berdampak pada ketepatan klasifikasi dan kodefikasi penyakit sehingga diagnosis dan kode diagnosis memiliki nilai informasif yang tepat dan lengkap. Selanjutnya informasi tersebut bisa dimanfaatkan dengan semaksimal mungkin. Sebagai contoh untuk statistik puskesmas. Informasi statistik terkait diagnosis dapat dimanfaatkan oleh puskesmas untuk mendukung dalam pengambilan keputusan dan penentuan kebijakan.

Puskesmas Nanggulan Kulon Progo melaksanakan persiapan Akreditasi Puskesmas 2015 selama sepuluh bulan.
Pelaksanaan yang dilaksanakan oleh puskesmas Nanggulan meliputi persiapan dari segi tenaga, metode, bahan, alat dan biaya. Kuhre $^{(6)}$ menyebutkan bahwa sumber daya tertentu perlu didapatkan sejak awal proses agar keseluruhan usaha dapat dilakukan dengan tuntas. Persiapan akreditasi yang dilaksanakan oleh Puskesmas Nanggulan Kulon Progo sudah sesuai dengan teori Kuhre $^{(6)}$ yaitu mempersiapkan sumber daya sejak awal proses dari keseluruhan kegiatan.

Analisis mengenai kegiatan persiapan dokumen Akreditasi Puskesmas 2015 tentang pembakuan kode berdasarkan unsur unsur manajemen yang terdiri dari $5 \mathrm{M}$ yaitu Man (tenaga), Materials (bahan), Methods (metode), Machines (mesin) dan money (biaya) di Puskesmas Nanggulan Kulon Progo, yaitu :

\section{Tenaga}

Permenkes Nomor 75 Tahun 2014 tentang Puskesmas menyebutkan bahwa Jenis dan jumlah Tenaga Kesehatan dan tenaga non kesehatan dihitung berdasarkan analisis beban kerja, dengan mempertimbangkan jumlah pelayanan yang diselenggarakan, jumlah penduduk dan persebarannya, karakteristik wilayah kerja, luas wilayah kerja, ketersediaan fasilitas pelayanan kesehatan tingkat pertama lainnya di wilayah kerja, dan pembagian waktu kerja.

Petugas rekam medis termasuk kedalam tenaga non kesehatan. Sehingga penambahan petugas rekam medis Puskesmas Nanggulan sudah sesuai dengan 
Permenkes Nomor 75 Tahun 2014 yaitu dengan melakukan analisis kebutuhan terlebih dahulu.

Kuhre $^{(6)}$ menyebutkan bahwa pertamatama sumber daya organisasi seperti personil, juga harus disusun apabila belum ada. Sehingga perekrutan yang dilaksanakan oleh Puskesmas Nanggulan Kulon Progo sudah sesuai dengan teori yang disampaian oleh Kuhre tersebut yaitu pengadaan personil yang belum ada berupa petugas rekam medis dengan latar belakang pendidikan rekam medis.

Proses persiapan dokumen Akreditasi Puskesmas 2015 yang dilakukan oleh Puskesmas Nanggulan Kulon Progo dilaksanakan dengan bentuk kerja dalam kelompok (tim) yang diorganisasikan dengan baik. Tim terdiri beberapa orang dengan latar belakang kemampuan yang berbeda namun selaras dengan pekerjaan yang akan dilaksanakan yaitu pembuatan dokumen terkait pembakuan kode.

Tracy $^{(7)}$ menyatakan bahwa teamwork merupakan kegiatan yang dikelola dan dilakukan sekelompok orang yang tergabung dalam satu organisasi. Teamwork dapat meningkatkan kerja sama dan komunikasi di dalam dan di antara bagian-bagian perusahaan. Biasanya team work beranggotakan orang-orang yang memiliki perbedaan keahlian sehingga dijadikan kekuatan dalam mencapai tujuan perusahaan.

Instumen Akreditasi Puskesmas dalam Permenkes Nomor 46 Tahun 2015 menyebutkan bahwa dokumen yang harus ada sesuai Elemen penilaian dari pembakuan kode yaitu dokumen dengan judul "SK tentang standarisasi kode klasifikasi diagnosis dan erminologi yang digunakan", "Standarisasi kode klasifikasi diagnosis dan terminologi di Puskesmas" dan "Pembakuan singkatan yang digunakan". Dokumen yang dibuat oleh Puskesmas Nanggulan Kulon Progo sesuai dokumen yang diharuskan ada berdasarkan elemen penilaian pada Instrumen Akreditasi Puskesmas 2015.

\section{Metode}

Sebelum pelaksanaan perekrutan Puskesmas Nanggulan Kulon Progo melakukan analisis kebutuhan tenaga. Elemen penilaian pada kriteria 2.2.2. Permenkes Nomor 75 Tahun 2015 tentang akreditasi menyebutkan agar puskesmas dapat memberikan pelayanan yang optimal dan aman bagi pasien dan masyarakat yang dilayani perlu dilakukan analisis kebutuhan tenaga dan diupayakan untuk memenuhi ketersedian tenaga baik jenis dan jumlah dan memenuhi persyaratan kompetensi. Adapun uraian elemen penilaian pada kriteri 2.2.2. adalah sebagai berikut yaitu dilakukan analisis kebutuhan tenaga sesuai dengan kebutuhan dan pelayanan yang disediakan. Ditetapkan persyaratan kompetensi untuk tiap-tiap jenis tenaga yang dibutuhkan. Dilakukan upaya untuk pemenuhan kebutuhan tenaga sesuai dengan yang dipersyaratkan. Ada kejelasan uraian tugas untuk setiap tenaga yang bekerja di Puskesmas. Persyaratan perizinan untuk 
tenaga medis, keperawatan, dan tenaga kesehatan yang lain dipenuhi.

Langkah-langkah perekrutan yang dilakukan oleh Puskesmas Nanggulan Kulon Progo sudah sesuai dengan elemen penilaian pada kriteria 2.2.2. Permenkes Nomor 75 Tahun 2015.

Setelah dilakukan analisis kebutuhan dan perekrutan selanjutnya dilakukan kegiatan orientasi, pengangkatan dan penempatan. Wether dan Davis (1996) menyebutkan :

Seleksi merupakan kegiatan suatu organisasi/institusi untuk memilih karyawan yang paling tepat, baik dalam jumlah mau pun mutu dari calon-calon yang ditariknya.

Orientasi ini merupakan masa penyesuaian diri, masa adaptasi diri dengan lingkungan kerja dan pekerjaannya.

Pengangkatan merupakan pembuatan perjanjian kerja. Perjanjian kerja merupakan suatu perjanjian yang dilakukan antara seorang tenaga dengan pemberi kerja. Perjanjian kerja mengatur tentang hak dan kewajiban dua belah pihak dalam perjanjian.

Mengarahkan calon pegawai yang potensial diberikan atau dipilih oleh unit yang memerlukan.

Bersadarkan artikel insanperforma(8) metode perekrutan karyawan dengan sumber dari luar perusahaan, dapat dilakukan yaitu melalui iklan di media massa (radio, TV, koran, internet). Melalui iklan atau adventensi diharapkan perusahan dapat merekrut calon tenaga kerja dengan spesifikasi tertentu dan dengan pengalaman kerja tertentu.
Perekrutan melalui iklan ini biasanya disertai dengan suatu janji yang menarik, misalnya gaji yang besar, masa depan yang menarik dan sebagainya.

Berdasarkan uraian di atas Puskesmas Nanggulan Kulon Progo menggunakan metode iklan di media masa melalui Dinas Kesehatan Kabupaten Kulon Progo .

Kegiatan dan hal yang dilaksanakan oleh tenaga untuk membuat dokumen akreditasi dan hal-hal yang berkaitan dan bermanfaat untuk mendukung persiapan dokumen akreditasi. Kegiatan dan hal-hal yang dimaksud diatas adalah sebagai berikut :

Puskesmas Nanggulan melaksanakan tiga kali kaji banding. Kaji banding memiliki pengertian yang serupa dengan studi banding. Sudana ${ }^{(9)}$ studi banding merupakan suatu kegiatan yang dilakukan dengan tujuan menambah wawasan dan pengetahuan yang akan diterapkan kedepannya untuk menjadi lebih baik. Kegiatan seperti ini tentunya sangat bagus bagi perkembangan suatu kebutuhan yang diharapkan sebagaimana mestinya.

Pengertian dari studi banding itu sendiri adalah sebuah konsep belajar yang dilakukan di lokasi dan lingkungan berbeda yang merupakan kegiatan yang lazim dilakukan untuk maksud peningkatan mutu, perluasan usaha, perbaikan sistem, penentuan kebijakan baru, perbaikan peraturan perundangan, dan lain-lan.

Kaji banding yang dilaksanakan oleh Puskesmas Nanggulan Kulon Progo berhasil 
menambah wawasan dan pengetahuan. Kemudian diterapkan dalam proses persiapan Akreditasi Puskesmas 2015.

Referensi yang dimaksud di Pukesmas Nanggulan Kulon Progo terbagi menjadi tiga yaitu yang pertama referensi untuk pembuatan dokumen yang berisi format dan aturan pembuatan dokumen, yang kedua referensi untuk isi Dokumen berupa dasar hukum, teori mau pun hasil penelitian peneliti lain yang menjadi pedoman dari isi yang kita cantumkan, dan yang ketiga referensi berupa contoh dokumen sehingga ada gambaran bentuk dari dokumen yang dimaksud itu seperti apa. $\mathrm{KBBI}^{(10)}$ menyebutkan bahwa referensi adalah sumber acuan (rujukan, petunjuk).

Sehingga referensi yang dipersiapkan oleh Puskesmas Nanggulan Kulon Progo sudah bermanfaat sebagaimana mestinya yaitu menjadi rujukan untuk proses pembuatan dan isi dokumennya.

Pedoman penyusunan dokumen akreditasi (2015) yang berasal dari Komisi Akreditasi Puskesmas menyebutkan Kebijakan adalah Peraturan/Surat Keputusan yang ditetapkan oleh Kepala FKTP yang merupakan garis besar yang bersifat mengikat dan wajib dilaksanakan oleh penanggung jawab maupun pelaksana. Berdasarkan kebijakan tersebut, disusun pedoman/panduan dan standar operasional prosedur (SOP) yang memberikan kejelasan langkah-langkah dalam pelaksanaan kegiatan di Puskesmas, Klinik Pratama, Dokter dan Dokter Gigi Praktik Mandiri.

Penyusunan Peraturan/Surat Keputusan tersebut harus didasarkan pada peraturan perundangan, baik Undang-undang, Peraturan Pemerintah, Peraturan Presiden, Peraturan Daerah, Peraturan Kepala Daerah, Peraturan Menteri dan pedoman-pedoman teknis yang berlaku seperti yang ditetapkan oleh Kementerian Kesehatan, Kementerian Dalam Negeri, Dinas Kesehatan Provinsi, dan Dinas Kesehatan Kabupaten/Kota. Peraturan/Surat Keputusan Kepala FKTP dapat dituangkan dalam pasal-pasal dalam keputusan tersebut, atau merupakan lampiran dari peraturan/keputusan.

\section{Bahan}

Bahan yang disiapkan oleh Puskesmas Nanggulan Kulon Progo untuk mendukung pembuatan dokumen Akreditasi Puskesmas 2015 berupa Alat Tulis Kantor (ATK). Novianto $^{(11)}$ menyebutkan bahwa Alat Tulis Kantor memang harus dan wajib ada untuk dipergunakan dalam pekerjaan tata usaha.

Berdasarkan pokok pikiran dari kriteria 9.1.3. pada Permenkes 75 tahun 2015 Mutu layanan klinis dapat ditingkatkan jika ada komitmen dari pihak pengelola Puskesmas dan tenaga klinis yang memberikan layanan klinis kepada pasien. Pimpinan Puskesmas perlu memfasilitasi, mengalokasikan dan menyediakan sumber daya yang dibutuhkan untuk kegiatan perbaikan mutu layanan klinis dan upaya keselamatan pasien sesuai dengan ketersediaan anggaran dan sumber daya 
yang ada di Puskesmas. Penyediaan bahan yang dilakukan oleh Puskesmas Nanggulan Kulon Progo sudah sesuai karena bahan tersebut digunakan untuk mempersiapkan dokumen akreditasi.

\section{Alat}

Berdasarkan pokok pikiran dari kriteria 9.1.3. pada Permenkes 75 tahun 2015 Mutu layanan klinis dapat ditingkatkan jika ada komitmen dari pihak pengelola Puskesmas dan tenaga klinis yang memberikan layanan klinis kepada pasien. Pimpinan Puskesmas perlu memfasilitasi, mengalokasikan dan menyediakan sumber daya yang dibutuhkan untuk kegiatan perbaikan mutu layanan klinis dan upaya keselamatan pasien sesuai dengan ketersediaan anggaran dan sumber daya yang ada di Puskesmas. Penyediaan alat yang dilakukan oleh Puskesmas Nanggulan Kulon Progo sudah sesuai karena alat tersebut digunakan untuk mempersiapkan dokumen akreditasi.

\section{Biaya}

Permenkes Nomor 46 Tahun 2015 tentang akreditasi menyebutkan bahwa Pendanaan penyelenggaraan Akreditasi, kegiatan pendampingan dan penilaian praakreditasi, serta pendampingan pascaakreditasi pada Puskesmas, Klinik Pratama, tempat praktik mandiri dokter, dan tempat praktik mandiri dokter gigi milik Pemerintah atau Pemerintah Daerah dibebankan kepada Anggaran Pendapatan dan Belanja Negara atau Anggaran Pendapatan dan Belanja Daerah.
Pembiayaan yang dilaksanakan oleh Puskesmas Nanggulan Kulon Progo dalam rangka mempersiapkan dokumen akreditasi sudah sesuai dengan uraian tersebut.

\section{KESIMPULAN}

Persiapan dokumen Akreditasi Puskesmas 2015 tentang pembakuan kode dengan judul "SK tentang standarisasi kode klasifikasi diagnosis dan terminologi yang digunakan di Puskesmas Nanggulan Kulon Progo", "Standarisasi kode klasifikasi diagnosis dan terminologi di Puskesmas Nanggulan Kulon Progo" dan "Pembakuan singkatan yang digunakan di Puskesmas Nanggulan Kulon Progo" berhasil. Akan tetapi penulisan diagnosis pada dokumen tersebut belum sesuai dengan ICD . Berikut ini merupakan persiapan dokumen akreditasi tentang pembakuan kode dari segi tenaga (sumber daya manusia) memegang peranan yang sangat penting karena tenaga memiliki peran dalam merencanakan pembiayaan terkait persiapan dokumen akreditasi, tenaga akan membentuk tim pembuat dokumen akreditasi, melaksanakan proses pembuatan dokumen menggunakan bahan dan alat. Metode yang berkaitan dengan persiapan dokumen yaitu proses pembentukan tim yang akan membuat dokumen dan proses pembuatan dokumen. Bahan yang diperlukan untuk mendukung persiapan dokumen akreditasi adalah alat tulis kantor. Alat yang diperlukan untuk mendukung persiapan dokumen akreditasi adalah mesin kantor 
seperti laptop (atau sejenisnya ) dan printer. Biaya diperlukan untuk mempersiapkan bahan, alat tenaga pelaksanaan persiapan dokumen.

\section{KEPUSTAKAAN}

1. Permenkes RI. Peraturan Menteri Kesehatan Republik Indonesia Nomor 75 Tahun 2014. <www.depkes.go.id.> Diakses tanggal 06 Januari 2016.

2. Hatta, Gemala R. Pedoman Manajemen Informasi Kesehatan di Sarana Pelayanan Kesehatan. Jakarta : Universitas Indonesia. 2008.

3. Permenkes RI. Peraturan menteri kesehatan Republik Indonesia Nomor 46 Tahun 2015. <www.depkes.go.id.> Diakses tanggal 06 Januari 2016.

4. Permenkes RI. Peraturan Menteri Kesehatan Republik Indonesia Nomor 27 Tahun 2014 Tentang Petunjuk Teknis Sistem Indonesian Case Base Groups (INA-CBGs). Jakarta : Menteri Kesehatan Indonesia.

5. Rahasti, May Eka. Hubungan Ketepatan Penulisan Diagnosis dengan Keakuratan Kode Diagnosis Pasien Rawat Inap di Rumah Sakit UGM Yogyakarta. Yogyakarta : UGM. 2016. Tidak dipublikasikan

6. Kuhre, W.L. ISO 14001 Certification Environmental Management System. USA : Prentice Hall, NJ. 1995.

7. Tracy, Brian. Pemimpin Sukses, Cetakan Keenam, Penerjemah: Suharsono dan Ana
Budi Kuswandani. Jakarta : Penerbit Pustaka Delapatrasa. 2006.

8. Insanperforma. Rekrutmen Karyawan : Definisi, Tujuan, Proses dan Sistem Rekrutmen. 2015. $<$ http://www.insanperforma.co.id/index.php ?option=com_content\&view=article $\& i d=14$ 3\%3Arekrutmen-karyawan-definisi-tujuanproses-dan-sistemrekrutmen\&catid=38\%3Anews\&lang.> Diakses pada 29 Maret 2016.

9. Sudana, Pengkuh Ibnu. Studi Banding. 2014.

<http://qmc.binus.ac.id/2014/10/28/pengerti an-studi-banding/.>Diakses pada 06 April 2016.

10. KBBI. Kamus Besar Bahasa Indonesia. <http://kamusbahasaindonesia.org.> 2016. Diakses tanggal 5 April 2016.

11. Novianto, Taufan. Perlengkapan Alat Tulis Kantor yang wajib tersedia. 2015. $<$ http://www.taufaner.web.id/2015/03/alattulis-kantor-wajib-tersedia.html.> Diakses pada 06 April 2016. 